\title{
Article
}

\section{High-Resolution Acoustic Cameras Provide Direct and Efficient Assessments of Large Demersal Fish Populations in Extremely Turbid Waters}

\author{
Céline Artero ${ }^{1,2, *} \mathbb{0}$, Simon Marchetti ${ }^{3}$, Eric Bauer ${ }^{3}$, Christophe Viala $^{4}$, Claire Noël ${ }^{3}$, Christopher C. Koenig ${ }^{2}$, \\ Rachel Berzins ${ }^{1}$ and Luis Lampert ${ }^{5}$ (i)
}

check for updates

Citation: Artero, C.; Marchetti, S.; Bauer, E.; Viala, C.; Noël, C.; Koenig, C.C.; Berzins, R.; Lampert, L. HighResolution Acoustic Cameras Provide Direct and Efficient Assessments of Large Demersal Fish Populations in Extremely Turbid Waters. Appl. Sci. 2021, 11, 1899. https://doi.org /10.3390/app11041899

Academic Editors: Jon Barry, Claire L. Szostek and Keith Cooper

Received: 29 January 2021

Accepted: 17 February 2021

Published: 22 February 2021

Publisher's Note: MDPI stays neutral with regard to jurisdictional claims in published maps and institutional affiliations.

Copyright: (c) 2021 by the authors. Licensee MDPI, Basel, Switzerland. This article is an open access article distributed under the terms and conditions of the Creative Commons Attribution (CC BY) license (https:// creativecommons.org/licenses/by/ $4.0 /)$.
1 Office Français de la Biodiversité (ex Office National de la Chasse et de la Faune Sauvage), 97338 Cayenne CEDEX, French Guiana; berzinsrachel@hotmail.com

2 Coastal and Marine Laboratory, Florida State University, St Teresa Beach, FL 32358, USA; ckoenig@fsu.edu

3 SEMANTIC T.S., 83110 Sanary-sur-Mer, France; marchetti@semantic-ts.fr (S.M.); bauer@semantic-ts.fr (E.B.); noel@semantic-ts.fr (C.N.)

4 Seaviews, 13600 La Ciotat, France; ch.viala@gmail.com

5 Institut Français de Recherche Pour l’Exploitation de la MER, Dyneco/Pelagos, 29280 Plouzané, France; luis.lampert@orange.fr

* Correspondence: artero.celine@gmail.com; Tel.: +33-(0)-676038745

\begin{abstract}
Monitoring fish species populations in very turbid environments is challenging. Acoustic cameras allow work in very poor visibility but are often deployed as a fixed observation point, limiting the scope of the survey. A BlueView P900-130 acoustic camera was deployed in rocky marine habitats off the coast of French Guiana in order to assess the total abundance, size structure and spatial distribution of a demersal fish population. The relevancy of using an acoustic camera to achieve these three objectives was evaluated by comparing acoustic data to those obtained from fishing surveys. The detection and identification of large demersal fish species were possible with the shape and size of the acoustic signal and acoustic shadow silhouette as well as swimming behavior. Mobile surveys combined with stationary surveys increased the probability of distinguishing individuals from inanimate objects. Estimated total length based on the acoustic signal underestimated the actual length of fish measured on deck, but the data showed the same trends in spatial and temporal variation. Acoustic cameras overcame the extreme lack of visibility by increasing knowledge of fish use of habitat, therefore providing much more efficiency in the effort, more accurate data on the abundance, size structure and spatial distribution than the fishing method. Thus, despite few limitations, acoustic camera surveys are far superior to fishing surveys in evaluating large demersal fish stock status.
\end{abstract}

Keywords: fish stock survey; turbid waters; acoustic camera; demersal fish; distribution; detectability

\section{Introduction}

Traditional methods used to study fish distribution and abundance generally require direct interaction with fishes in their natural environment [1]. Such methods include direct visual or video assessments or various types of fishing. In clear, calm waters, fish may be readily identified and counted at distances up to 15 meters by divers or by remote video systems [2,3]. However, in highly turbid waters where visibility is low or absent, visual and video methods are ineffective [4]. Various fishing methods are typically highly variable and uncertain because results depend on the behavior of fish [5]. Fishing methods may also be intrusive, hurting or killing fish. Thus, the most reliable methods are non-intrusiveness visual/video methods, but low visibility severely constrains such methods.

Acoustic systems such as echo sonars or multibeam sonars are not limited by light level or visibility because the image is produced by reflected sound, not reflected light $[6,7]$. High-frequency multibeam sonars or "acoustic cameras" are a relatively new technology, 
which was formerly used for surveillance and inspection of structures in the marine environment [8]. They are being used increasingly to study marine fish populations and were adapted for fish enumeration or identification under conditions of low visibility, such as poor lighting or high turbidity $[6,7,9,10]$. These acoustic systems provide high-quality images with similar resolution as standard videos [3].

Among existing materials, fishery scientists have principally used the Sound Metrics Corp. DIDSON dual-frequency identification sonar [1,8,11-19]. DIDSON allows researchers to operate at several frequencies, the highest of which is $1.8 \mathrm{MHz}$, which produces high image quality with a $29^{\circ}$ field of view. The maximum distance for this frequency is about $12 \mathrm{~m}$, but this distance may be increased to $30 \mathrm{~m}$ with a lower frequency of 1.1 MHz [9]. Fish species can also be distinguished with a Teledyne "BlueView P900$2250^{\prime \prime}$ high-frequency multibeam sonar and at a frequency of $1 \mathrm{MHz}$, even pectoral and caudal fins could be discerned to identify individuals and fish species [20]. BlueView sonar equals DIDSON in the quality of images [21]. Both types of acoustic cameras are deployed to count pelagic fish in horizontal and stationary surveys (in one site) in shallow waters. As example, it is possible to count moving salmonid fishes [1,18,22], and to measure reef fish abundance [23]. With appropriate software (Sound Metrics software or ProViewer software), it is possible to measure the length of individuals $[8,15,19]$ and to study their behavior [24-27]. A double protocol, using both static and mobile acoustic cameras was developed to study the abundance of the Kamchatka steelhead (Parasalmo mykiss) in a river that allow describing the size structure of the species [17]. Recently, the spatial distribution of fish populations has been described using acoustic cameras. Indeed, the density and spatial distribution of pelagic fish was assessed by deploying an acoustic camera in a lake [28]. Few studies focused on demersal fish even if identification through acoustic shadows is possible [3]. However, immobile individuals on the bed cannot be detected and may be problematic for abundance estimates [29].

Fish biodiversity in French Guiana is very high, but only a few species are of commercial importance: Siluriformes Ariidae (Sciades proops), Perciformes Sciaenidae (Cynoscion acoupa), Lutjanidae (Lutjanus vivanus), Scrombidae (Acanthocybium solandri), Haemulidae (Genyatremus luteus) and Serranidae (Epinephelus itajara). Epinephelus itajara, commonly named the goliath grouper, is a demersal species that inhabits bays, estuaries, mangroves, artificial reef and rocky sites, inshore as well as offshore [30-33]. It is a valuable commercial fish species in French Guiana when, at the time of the study, it was protected in other countries and listed as a critically endangered species in the IUCN red list, principally because of overfishing [34]. In the vicinity of the Grand Connétable Islands, classified as Marine Protected Area in 1992, fishing is forbidden, so the fish and marine bird species are protected. From a fish population management perspective, following and understanding the dynamics of the fish population is the first step to regulation policy.

However, the marine waters of French Guiana present extreme turbidity, not only inshore due to the influence of local rivers (Approuague, Mahury) [35-37] and the resuspension of mudflat sediments $[35,36,38]$ but also offshore due to the Amazon River, the world's most turbid region with a diffuse attenuation coefficient $\left(K_{\mathrm{d}}(490)\right)$ superior to $5 \mathrm{~m}^{-1}$ [39]. Indeed, the largest river of the world discharges nearly 100 million tons of sediment in marine waters per year [40], which is then carried along the French Guiana coasts up to the Caribbean Sea [41] via the north Brazil current [42]. Therefore, the extremely turbid conditions of the near-shore marine environment of French Guiana limit the possible methods to study fish distribution or abundance and knowledge on the local fish ecology is scarce. The objective of this study was to evaluate the reliability of the P900-130 BlueView acoustic camera to study fish population ecology, including identification, abundance, spatial distribution and size structure in extreme turbid conditions in order to apply this methodology for annual fish population survey

An ideal demersal species for evaluating acoustic camera capabilities under low visibility is the goliath grouper. This species has morphological (maximum length of $2.50 \mathrm{~m}$ ) and ecological characteristics that could facilitate (1) its identification through acoustic beam 
as well as (2) the approximation of the total abundance of the local population. Indeed, goliath groupers are strongly linked to their rocky habitat with really short daily distance movements [32], except during reproduction periods [43,44]. Therefore, by implementing an exhaustive survey of rocky sites, the total counted individuals approximate the total abundance of the local population. Moreover, a scientific fishing survey led simultaneously allowed studying the consistency of the acoustic camera results compared to usual fishing surveys. The present study aimed at (1) investigating the possibility of identifying demersal fish species through an acoustic camera, (2) analyzing replication and accuracy of abundance and total length estimations with acoustic cameras and (3) comparing spatial distribution provided from fishing data and acoustic camera. The final purpose was to know if acoustic cameras would be efficient tools to realize spatial and temporal surveys of demersal fish populations.

\section{Materials and Methods}

\subsection{Study Sites}

Acoustic field sampling was conducted over 4 days in September 2011 and 4 days in September 2012. Sampling locations were on rocky marine sites off the eastern coast of French Guiana from Mahury River Estuary to Oyapock River Estuary (Figure 1A). Rocky sites were pooled into two areas (Table 1).

The Rémire islands are composed of 5 islands: Le Malingre, Le Père, La Mère and les Mamelles; the last actually composed of 2 small islands in close proximity.

The Grand Connétable Island Marine Protected Area (MPA) is composed of 2 islands, Grand Connétable and Petit Connétable.
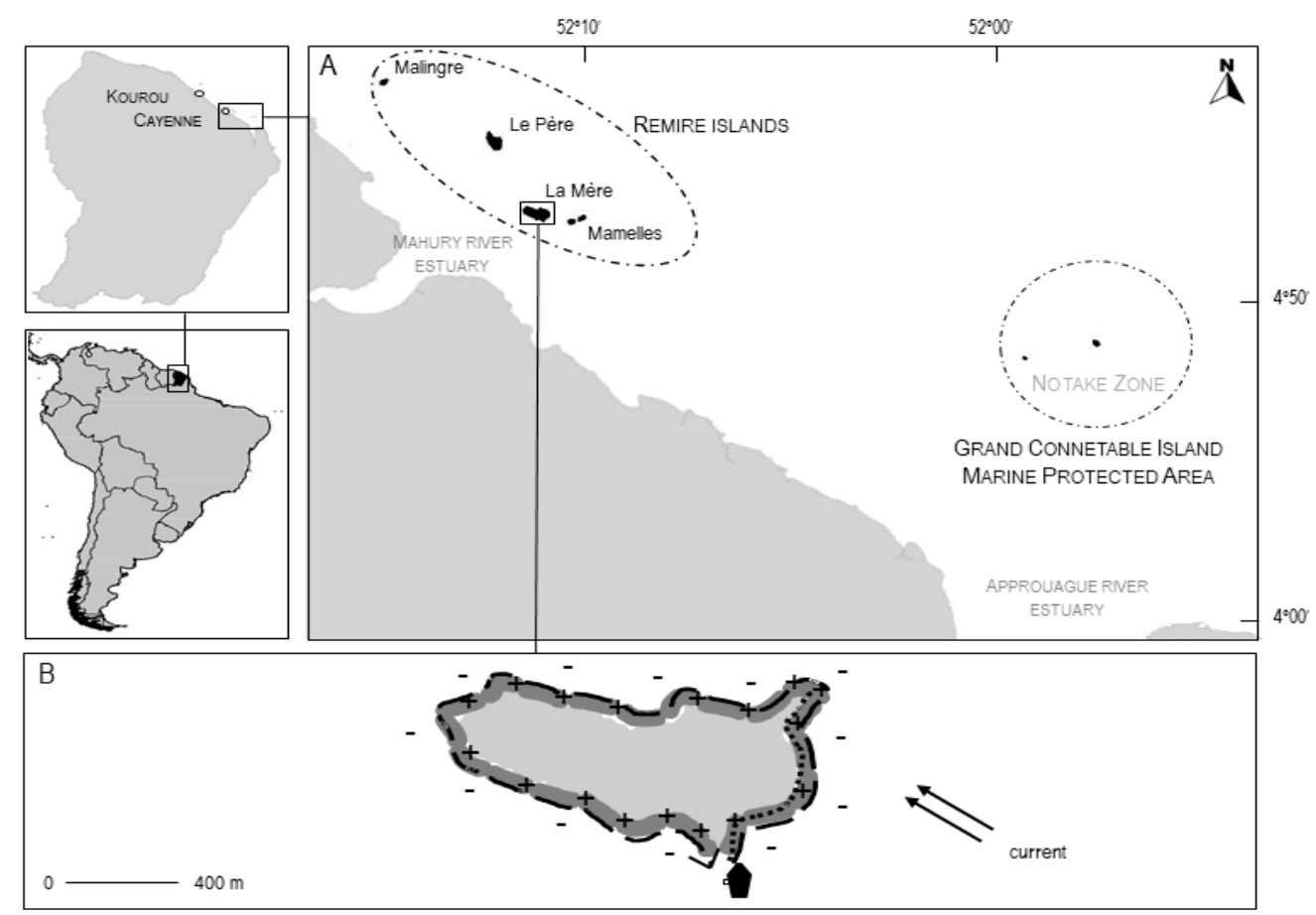

Figure 1. (A) Marine rocky islands of eastern French Guiana where goliath groupers (Epinephelus itajara) were sampled acoustically and by fishing. (B) La Mère island (Rémire islands) showing acoustic camera deployment from the boat (dash line) and fishing locations (dotted line). Dark gray zone indicates the field of view of the acoustic camera $(+)$ indicates the presence of rock, $(-)$ the presence of mud and arrows indicate the prevailing marine current. 
Table 1. Characteristics of Rémire islands and Grand Connétable Island Marine Protected Area, rocky islands of French Guiana.

\begin{tabular}{cccc}
\hline Site & Perimeter $\mathbf{( k m )}$ & Depth $(\mathbf{m})$ & Facies \\
\hline Rémire Islands & & & \\
Mamelles & 2.3 & $0.5-4.5$ & Rocky screes \\
La Mère & 4.4 & $1.5-5$ & Screes, large boulders \\
Le Père & 3 & $1.5-7$ & Large boulders, walls \\
Malingre & 1.1 & $1-5$ & Large boulders, walls \\
Grand Connétable Island MPA & & & Large boulders, walls \\
Petit Connétable & 0.8 & $4-10$ & Walls \\
Grand Connétable & 0.3 & $5-9$ & \\
\hline
\end{tabular}

\subsection{Acoustic Camera}

The P900-130 BlueView (Teledyne Marine) high-frequency sonar has a field-of-view of $130^{\circ}$ lateral angle and $20^{\circ}$ vertical angle (Figure 2). An acoustic frequency of $900 \mathrm{kHz}$ enables sound emission through 768 beams ( $1^{\circ}$ lateral angle) with $0.18^{\circ}$ space between each beam. Theoretically, the maximal distance for the detection of fish is equal to $100 \mathrm{~m}$, but the optimal distance is between 2 and $60 \mathrm{~m}$.

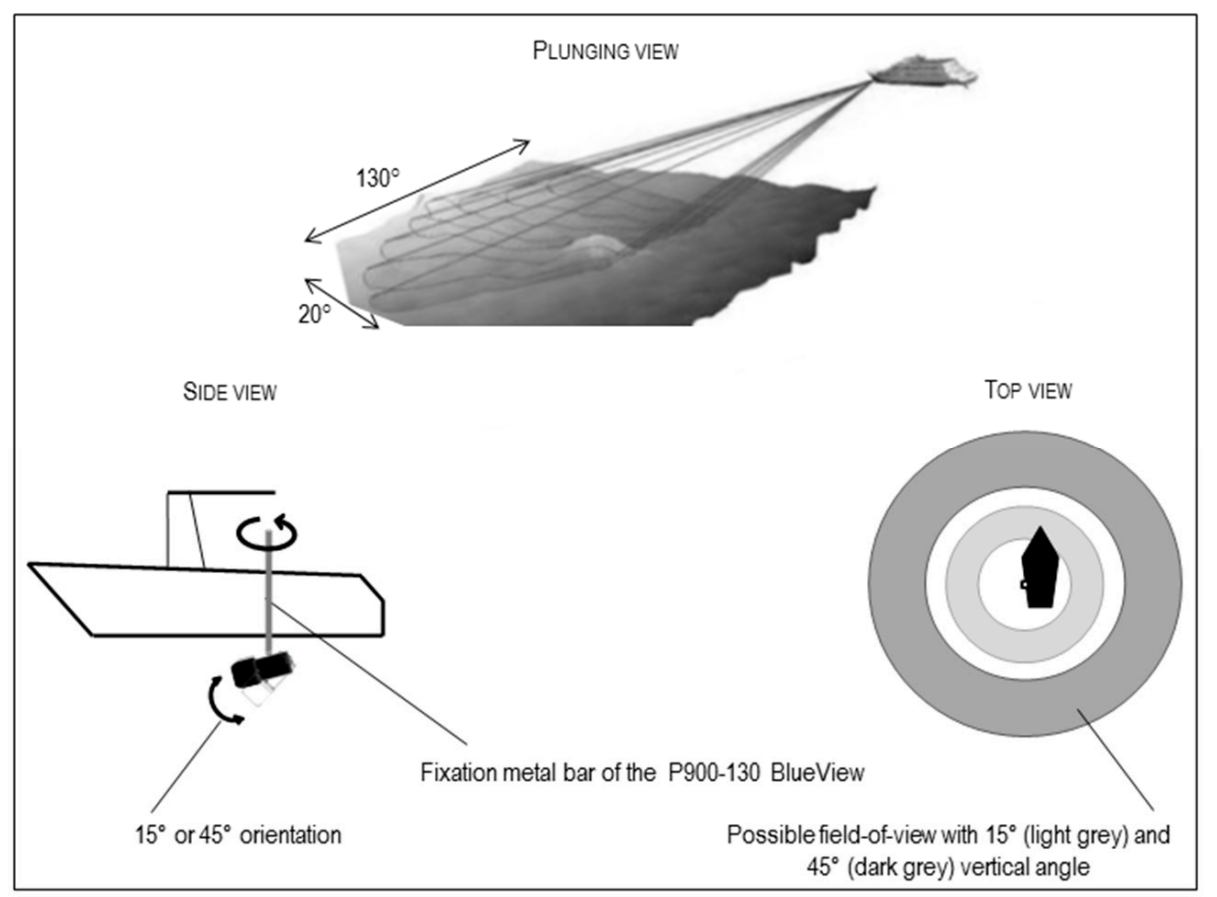

Figure 2. Diagram of the P900-130 BlueView acoustic camera installation on a boat and its field-ofview for demersal fish survey in French Guiana.

The acoustic camera system included a $12 \mathrm{~V}$-powered laptop computer, a high storage capacity internal drive that recorded videos in real time and a GPS system for georeferencing. The acoustic camera was mounted on the port side of the boat at the bottom of a vertical $3 \mathrm{~cm}$ diameter metal bar. The camera was submerged to a depth of $80 \mathrm{~cm}$ (slightly below the hull of the vessel) and could be rotated $360^{\circ}$ and oriented vertically between $15^{\circ}$ and $45^{\circ}$ off horizontal (Figure 2).

\subsection{Survey Description}

Two types of surveys were conducted: mobile surveys that covered the entire habitat of the studied species and stationary surveys to minimize bias of undetected individuals. 
During the mobile survey, the acoustic camera was aimed $90^{\circ}$ to the axis of the vessel, so the field-of-view was $90^{\circ}$ to the heading off starboard. Surveys around each island were done following the island coastlines in a counter-clockwise direction approximately $50 \mathrm{~m}$ away from the coast so that the survey would extend from our boat to shore at a speed of about $2 \mathrm{~m} \cdot \mathrm{s}^{-1}$ (Figure 1B). Surveys represented from 0.8 to $4.4 \mathrm{~km}$ perimeter long depending on islands size. Each mobile survey consisted of two runs around an island, one with the vertical orientation of the camera at $15^{\circ}$, and one at $45^{\circ}$.

The stationary surveys were conducted over a $15 \mathrm{~min}$ period from an anchored boat. The camera was slowly rotated $360^{\circ}$ at $15^{\circ}$ for $7 \mathrm{~min}$, then at $45^{\circ}$ vertical angles for $7 \mathrm{~min}$ more (Figure 2). One to three stations were sampled per island depending on the size of the island and the number of goliath grouper fishing locations known from previous fishing surveys. Because the Rémire islands were greater in number than the MPA islands, we made a total of 8 stationary samples around the Rémire islands and 3 around the MPA islands.

A total of $12 \mathrm{~km}$ of rocky coasts were surveyed at a rate of about $4 \mathrm{~h}$ per island.

\subsection{Acoustic Data Treatment}

An operator with strong knowledge of French Guiana fish species and their ecology analyzed the acoustic data.

Identification: Identification of demersal species was attempted via morphological criteria of the acoustic signal and acoustic shadow (a fish within an acoustic beam produces a shadow representing its silhouette, just as a fish does in a light beam) as suggest by [20] and [3], respectively.

Validation of the identification: Because of the extreme turbidity in French Guiana waters, it was not possible to use video images to validate the identification of fish on acoustic images. Acoustic imagery was validated during fishing surveys, where an acoustic camera survey was conducted at the same time as the capture of individuals with fishing rods. When brought aboard the vessel, individuals were subsequently identified, measured then released alive. Acoustic camera signals of the captured fish were therefore associated with a specific fish species.

Acoustic videos analyses: ProViewer 3.6, CBlueView Technologies, Inc software, Slangerup, Denmark, 2011 allowed visualization of the acoustic files with "son" format. Several tools were available to analyze the acoustic videos (scroll rate setting, measure of items, zoom, and acoustic wave representation mode) that allowed watching videos as many times as necessary to identify and measure fish.

Counting: To avoid counting the same fish twice during stationary acoustic surveys, individuals that left the field-of-view were only counted as new fish upon return if they were a different size than the fish that left or if they were the same size but appeared more than 2 min later. In the same way, counting errors between mobile and stationary surveys were reduced by removing the same size individuals detected at the exact same location.

To verify the consistency of counts during mobile surveys, they were run with the same vertical view angle twice on two islands (Mamelles and Grand Connétable). Mamelles islands surveys were run one day apart, and Grand Connétable Island surveys were run a few minutes apart.

Measure: Size measurements of the same fish were made when fish signals were straight (tail lined up with the head and not curved during swimming undulations) at least two times with ProViewer software. The measurement tool of the ProViewer software provided a precision of the measure of $\pm 10 \mathrm{~cm}$. Because the orientation of the fish may reduce the estimate of actual size (and because this error of measurement cannot be estimated, Figure 3), the largest size measured of a single fish was considered the best measure. 

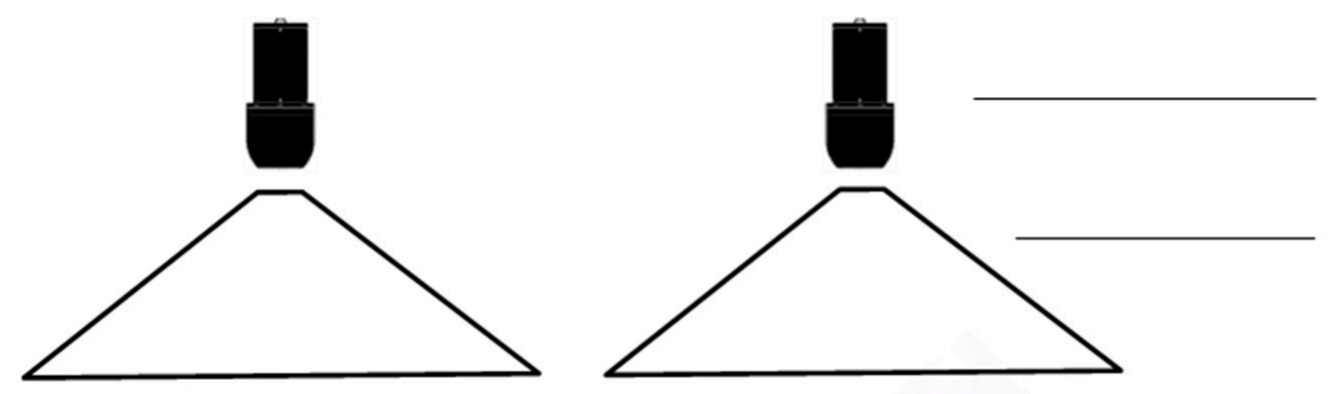

Acoustic camera

Acoustic beam

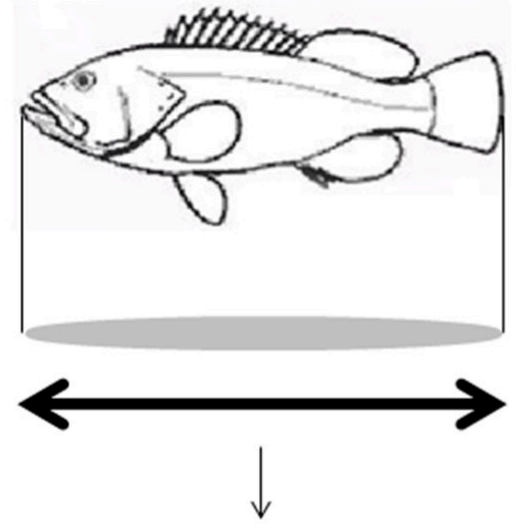

Correct measurement

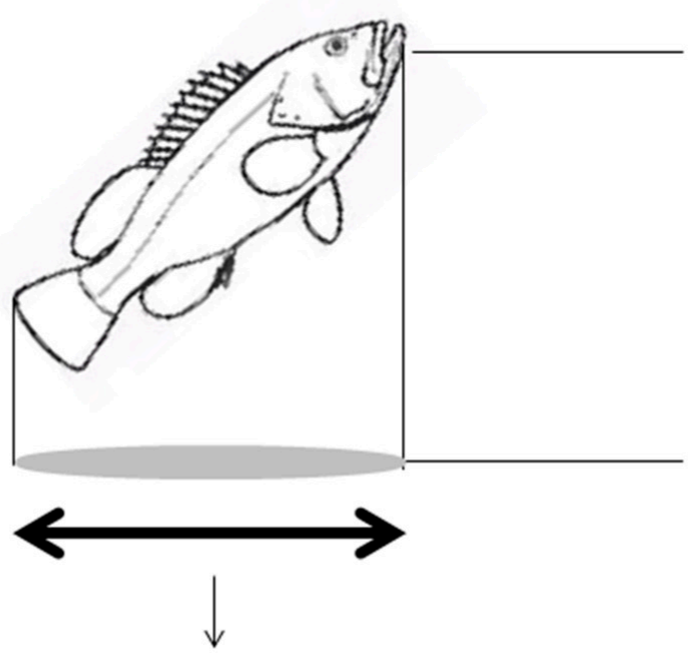

Angle of the fish with the acoustic camera

Fish acoustic signal

Figure 3. Scheme of measurement error of fish with an acoustic camera.

\subsection{Scientific Fishing}

Fishing surveys were organized during the same period as the acoustic one. General objectives of fishing surveys were to study the spatial distribution of fish, territoriality (mark/recapture method), to collect samples and to assess the population's total abundance.

As goliath groupers in French Guiana were extremely territorial and presented no movement pattern between rocky islands (with perhaps the exception for the reproduction migration once a year (in July-August) where mature individuals may leave the area [45]), this work was based on the assumption that the population parameters (abundance, distribution and size range) stay identical year-round. In this way, one year of fishing data will bring the most representative data for this population. That is why data collected during the fishing survey would allow a comparison with acoustic camera data except for abundance, which was not possible to estimate with fishing data due to low participation of fishermen reporting recaptures.

Scientific fishing trips were constrained by seasonal weather conditions in French Guiana (high sea states were common from January to March). Hence, fishing was scheduled once a week from April to December in 2011 and 2012. Study sites were visited at least once a month. A total of 68 fishing trips were made (Table 2).

Goliath grouper specimens were captured with heavy-duty fishing rods and special fishing gear (non-stainless steel circle hook, no barb) to avoid fatal injuries to the fish [46,47]. All specimens were tagged, measured as the straight-line distance from the tip of the upper jaw to the end of the tail (total length $\mathrm{LT}, \pm 1 \mathrm{~cm}$ ) and released alive.

The current direction is relatively constant in a westerly direction throughout the year in French Guiana. Because the goliath grouper is restricted to rocky habitats, fishing was limited to the windward side of islands; otherwise, baits moved away to muddy areas with the current (Figure 1B). 
Since goliath grouper populations in French Guiana are composed of the same individuals year-round, total lengths of individual goliath groupers measured during fishing (representing real size) were compared to lengths measured in acoustic images in order to evaluate the reliability of acoustic camera measurement. Because variances of data were not homogeneous, mean total lengths were compared using a nonparametric test (Wilcoxon) with R software, version 3.3.2 (www.r-project.org (accessed on 13 October 2014)).

Table 2. Number of goliath groupers counted around rocky sites using the acoustic camera and fishing in 2011 and 2012 . N survey: number of fishing trips.

\begin{tabular}{|c|c|c|c|c|c|c|c|c|c|c|}
\hline & \multicolumn{5}{|c|}{2011} & \multicolumn{5}{|c|}{2012} \\
\hline & \multicolumn{3}{|c|}{ Acoustic Camera Survey } & \multirow{2}{*}{ Fishing } & \multirow{2}{*}{ N Survey } & \multicolumn{3}{|c|}{ Acoustic Camera Survey } & \multirow{2}{*}{ Fishing } & \multirow{2}{*}{ N Survey } \\
\hline & Mobile & Stationary & Total & & & Mobile & Stationary & Total & & \\
\hline Mamelles & 3 & 17 & 20 & 5 & 7 & 18 & 0 & 18 & 7 & 8 \\
\hline La Mère & 33 & 0 & 33 & 1 & 3 & 17 & 0 & 17 & 2 & 4 \\
\hline Le Père & 23 & 14 & 37 & 3 & 5 & 39 & 6 & 45 & 3 & 4 \\
\hline Malingre & - & 0 & 0 & 1 & 2 & 6 & 0 & 6 & 1 & 3 \\
\hline $\begin{array}{l}\text { TOTAL Rémire } \\
\text { Islands }\end{array}$ & 59 & 31 & 90 & 10 & 17 & 80 & 6 & 86 & 13 & 19 \\
\hline Petit Connétable & 26 & 0 & 26 & 15 & 19 & 29 & 7 & 36 & 3 & 10 \\
\hline Grand Connétable & 93 & 8 & 101 & 105 & 2 & 31 & 10 & 41 & 65 & 1 \\
\hline $\begin{array}{l}\text { Grand Connétable } \\
\text { Island MPA }\end{array}$ & 119 & 8 & 127 & 120 & 21 & 60 & 17 & 77 & 68 & 11 \\
\hline TOTAL & 178 & 39 & 217 & 130 & 38 & 140 & 23 & 163 & 81 & 30 \\
\hline
\end{tabular}

\section{Results}

\subsection{Demersal Species Identification Through Acoustic Camera}

Several demersal species, when moving, were detected with the acoustic camera. Identification of species having a distinguishable silhouette, such as rays, marine turtles, and sharks (Figure 4A-C, respectively), could be identified easily, whereas fish with a typical fusiform shape were more difficult to identify without additional information (Figure 4D). For this reason, important work on methodology development was done to identify the targeted species among other fish species.
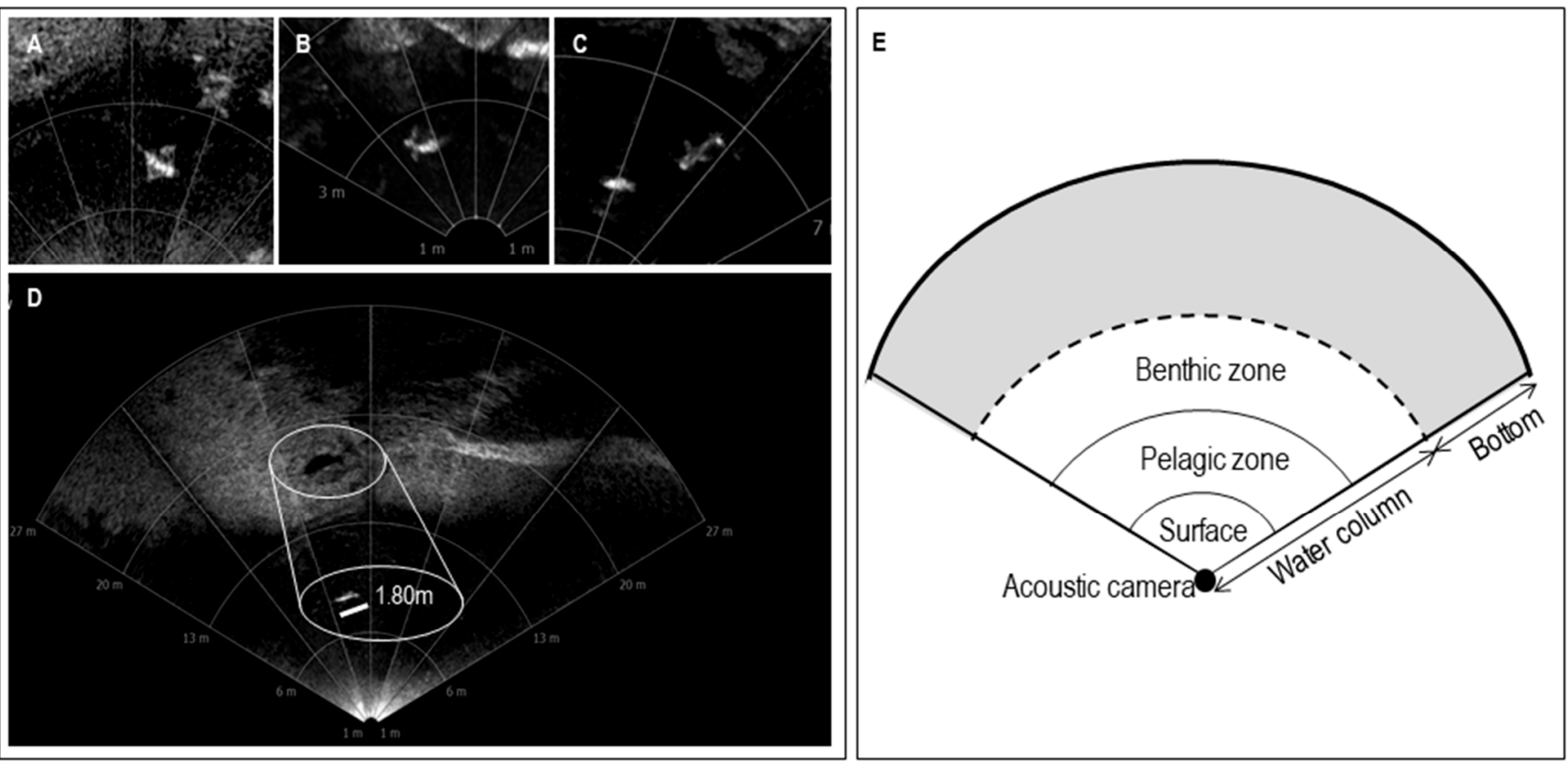

Figure 4. Detection of a ray (A), a marine turtle (B), a shark (C), a goliath grouper (Epinephelus itajara) with its corresponding acoustic shadow (D) and scheme of the determination of the fish position in the water column (E) with a P900-130 BlueView acoustic camera. 
Adding to morphological criteria of the acoustic signal and the silhouette of the acoustic shadow, other parameters could be considered in identifying species, such as (1) the behavior of the fish (swimming or aggregating behavior), and (2) the depth of the fish, evaluated from the fish signal position in relation to the acoustic video scale (see on Figure 4E). In this way, goliath groupers were identified in acoustic images using four combined morphological and behavioral characteristics: (1) body width relative to the length of the species produces a massive acoustic image, bulkier than other species, (2) length of fish tends to be large (up to $2.50 \mathrm{~m}$ ), especially compared with other grouper species $(<40 \mathrm{~cm})$ living in similar habitats, (3) swimming behavior, because grouper show a distinctive swimming style with slow tail undulation relative to other fish that could reach a similar size like mackerel (Scomberomorus sp.) or tarpon (Megalops atlanticus) and (4) the depth of occurrence (near the bottom) since other fish species do not use the same area of the water column (pelagic fish). Thus, with prior knowledge of fish species silhouette, their behavior and the depth of occurrence, it was possible to identify fish species from acoustic images. However, because of the difficulty of distinguishing very small individuals $(<40 \mathrm{~cm})$ from other species, they were not included in the present study.

Seven individuals with a characteristic acoustic image showing obvious morphology, slow swimming behavior, large size and a demersal position were caught on rocky study sites during the combination of both acoustic camera and fishing surveys. All seven were confirmed as goliath groupers. No other fish were caught during these combined surveys.

\subsection{Length of Fish}

The measurement of fish observed during a campaign with both acoustic and fishing surveys highlighted no difference between measurement methodologies (Mann-Whitney, $p>0.05$ ) even when the average sizes estimated using the acoustic camera were $13 \mathrm{~cm}$ smaller than the actual size (Table 3).

Table 3. Real and estimated total length with variation $(\mathrm{cm})$ of the seven fish observed during simultaneous acoustic camera and fishing campaigns.

\begin{tabular}{cccc}
\hline Fish & $\begin{array}{c}\text { Size Measured during } \\
\text { Fishing Survey }\end{array}$ & $\begin{array}{c}\text { Size Estimated with an } \\
\text { Acoustic Camera }\end{array}$ & Variation \\
\hline 1 & 101 & 90 & -11 \\
2 & 122 & 80 & -42 \\
3 & 171 & 170 & -1 \\
4 & 124 & 120 & -4 \\
5 & 112 & 100 & -12 \\
6 & 120 & 110 & -10 \\
$7^{*}$ & - & 100 & - \\
Mean & $\mathbf{1 2 5}$ & $\mathbf{1 1 2}$ & $\mathbf{- 1 3}$ \\
\hline
\end{tabular}

* Fish 7 escaped before size measurement and was not included in the calculation of the size mean and size comparison.

\subsubsection{Total Length Estimated with the Acoustic Camera}

Over the entire study area, the mean total length of the goliath groupers observed with the acoustic camera was not significantly different between $2011(85.9 \pm 30.8 \mathrm{~cm})$ and 2012 (83.6 $\pm 23.7 \mathrm{~cm}$; Mann-Whitney, $p>0.05)$. No temporal evolution was highlighted in each study site either (Mann-Whitney, $p>0.05$, Figure 5).

In both years, individuals detected around Rémire islands were significantly smaller (73.5 $\pm 26.4 \mathrm{~cm}$ in 2011 and $78.6 \pm 22.5 \mathrm{~cm}$ in 2012) than individuals detected around the Grand Connétable Island MPA $(99.3 \pm 28.7 \mathrm{~cm}$ in 2011 and $89.9 \pm 26.3 \mathrm{~cm}$ in 2012; Mann-Whitney, $p<0.05$ ). 


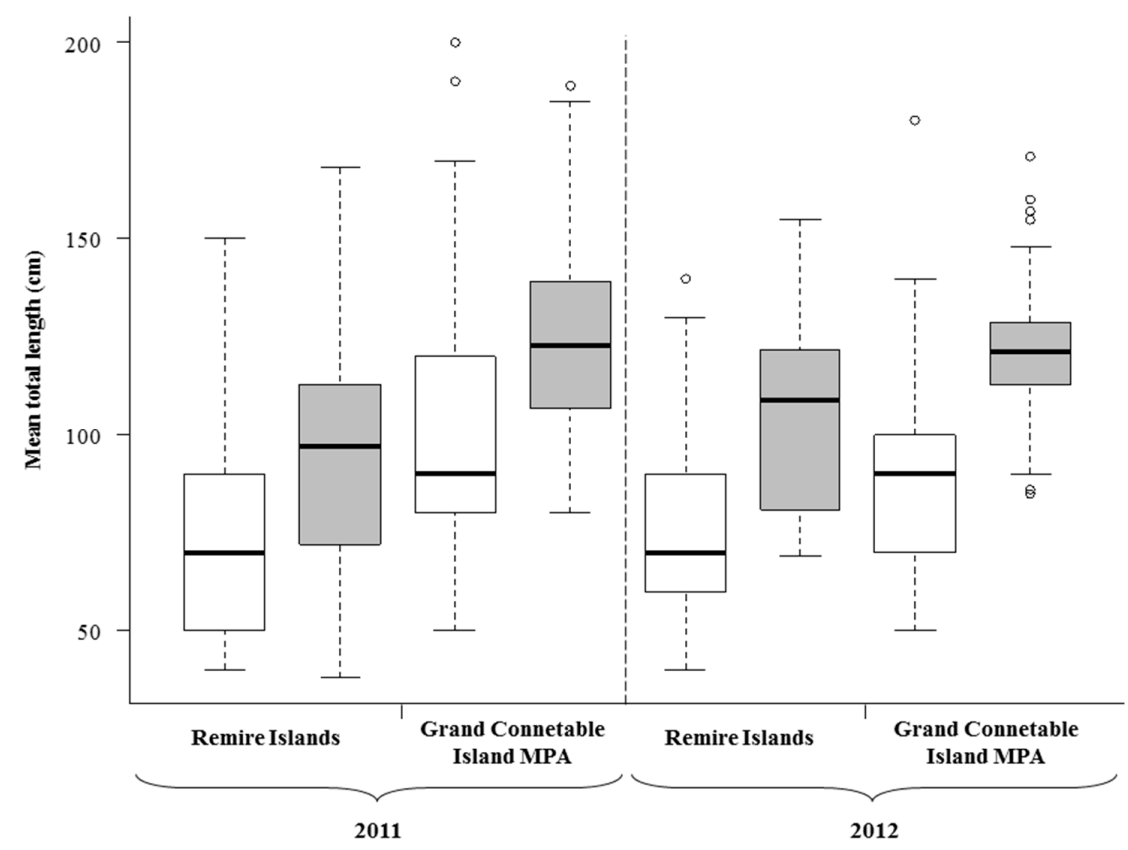

Figure 5. Mean total length $(\mathrm{cm})$ of goliath groupers (Epinephelus itajara) estimated with a P900-130 BlueView acoustic camera (white box) and measured during fishing trips (gray box) around rocky islands of French Guiana in 2011 and 2012.

\subsubsection{Measured Total Length by Fishing}

Overall, the mean total length of the captured goliath groupers was not significantly different between 2011 and $2012(121.7 \pm 28.6 \mathrm{~cm}$ and $119.4 \pm 19.3 \mathrm{~cm}$, respectively; MannWhitney, $p>0.05)$. In addition, the mean total length was not significantly different at each sampled area between 2011 and 2012 (Mann-Whitney, $p>0.05$ ). In both years, individuals caught around Rémire islands were significantly smaller $(95.3 \pm 34.9 \mathrm{~cm}$ in 2011 and $106.4 \pm 27.7 \mathrm{~cm}$ in 2012) than individuals of Grand Connétable Island MPA $(123.7 \pm 28.5 \mathrm{~cm}$ in 2011 and $121.7 \pm 19.3 \mathrm{~cm}$ in 2012; Mann-Whitney, $p<0.05$ ).

Whatever the area or the year, the total length estimated with the acoustic camera was always significantly lower than the total length of captured individuals (Mann-Whitney, $p<0.05$; Figure 5). On average, there was a $26.4 \pm 4.3 \mathrm{~cm}$ difference between the measurement methods.

\subsection{Abundance of Demersal Fish}

In September 2011, a total of 217 goliath groupers were counted via acoustic camera around rocky islands and 163 individuals in September 2012.

Differences in abundance occurred between the two studied areas. In 2011, a total of 90 individuals were identified around Rémire islands and 127 individuals around the Grand Connétable Island MPA. In September 2012, the number of goliath groupers was slightly lower in both sites, with a total of 86 individuals at Rémire islands and 77 at the Grand Connétable Island MPA (Table 2).

Stationary surveys increased the number of individuals detected during the mobile survey by $16 \pm 2 \%$, with 39 additional individuals in 2011 and 23 individuals in 2012 (Table 2).

Counting repeated once around the two sites yielded similar results with one individual difference each time (Table 4). 
Table 4. Repeatability of goliath groupers (Epinephelus itajara) counting with a P900-130 BlueView acoustic camera.

\begin{tabular}{ccc}
\hline Site & Count 1 & Count 2 \\
\hline Mamelles & 20 & 21 \\
Grand Connétable & 95 & 94 \\
\hline
\end{tabular}

Because some fishermen did not return information on recaptures, estimation of the abundance of the goliath groupers via the fishing survey was not possible. The results presented are the count of caught fish.

The number of individuals caught at the Grand Connétable Island MPA in 1 year represented more than $84 \%$ of the total catch of the studied areas. Indeed, 10 and 13 individuals were caught around Rémire islands in 2011 and 2012, respectively, and 120 and 68 individuals were caught at the Grand Connétable Island MPA area in 2011 and 2012, respectively. The number of individuals caught in the MPA was reduced by one-half between 2011 and 2012, while the number of individuals was nearly constant in Rémire islands (Table 2).

\subsection{Spatial Distribution of Demersal Fish}

Whichever the methodology was used, individuals were observed very close $(<20 \mathrm{~m})$ to the rocks, with the exception of one individual caught $60 \mathrm{~m}$ away from the rock. Most of the individuals (98\%) caught during the fishing surveys were located on the east and southeast sides of the islands (Figure 6). Acoustic surveys highlighted a more widespread spatial distribution, with acoustic detections all around the islands (Grand Connétable Island MPA), with the exception of the southwest side (Rémire islands, Figure 6).
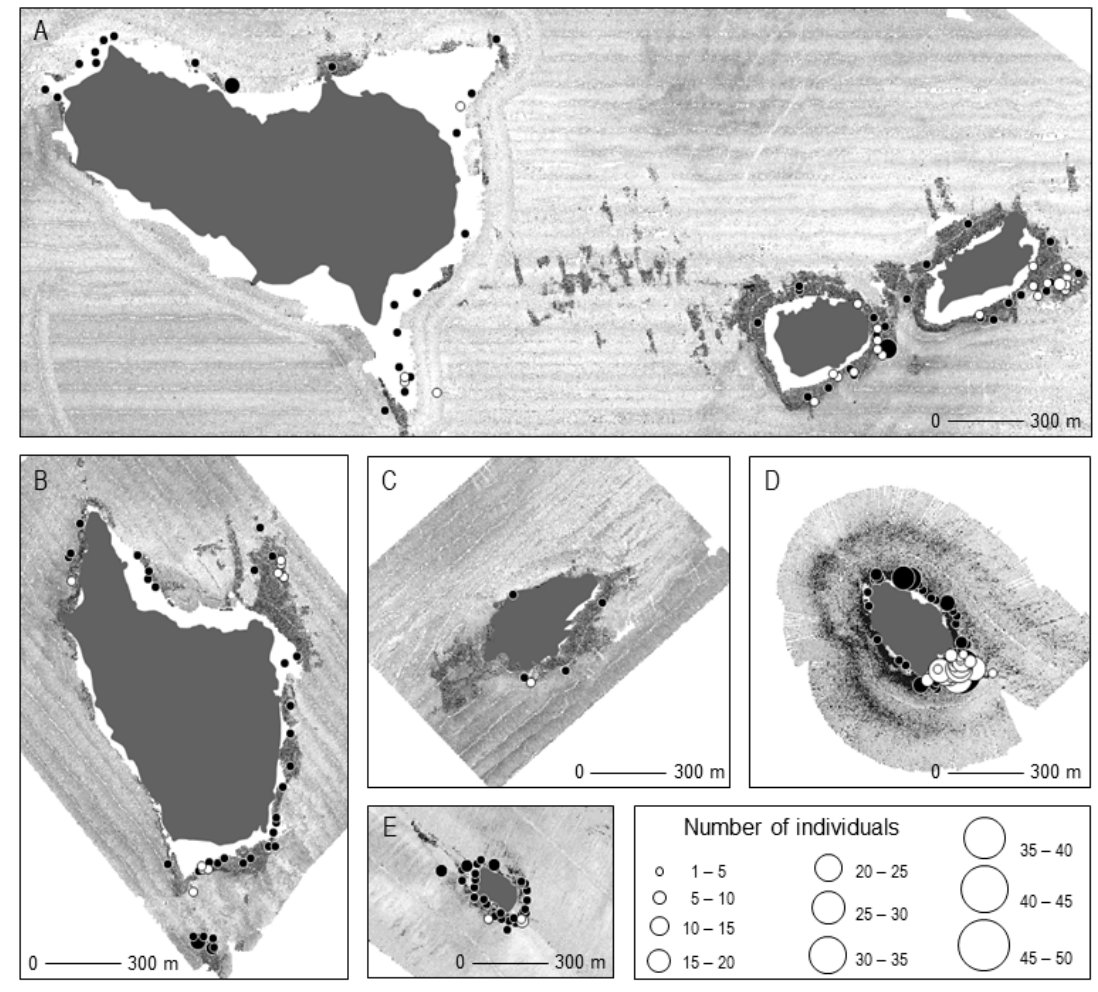

Figure 6. Spatial distribution of goliath groupers (Epinephelus itajara) around Rémire islands (A) La Mère and Mamelles, (B) Le Père, (C) Malingre) and in the Grand Connétable Island Marine Protected Area ((D): Grand Connétable, (E): Petit Connétable). Gray shaded: bottom substrate type (light gray for mud and sand; dark gray for rock, obtained from side-scan sonar mapping). White points: fishing observations, black points: acoustic camera observations. 


\section{Discussion}

\subsection{Detectability of Demersal Fish with P900-130 BlueView Acoustic Camera}

Until recently, many studies using an acoustic camera have focused on pelagic fish $[18,21,48]$. The use of acoustic cameras with the specific goal of studying demersal species was mentioned once [29], but mullet, eels, and barbel were identified during scientific surveys [3,49]. Benthic species on the sediment could be confused with inanimate objects, but remaining in a stationary position for 15 minutes increased the probability of detecting motionless individuals if they move in that time frame.

In this study, the goliath grouper was chosen as a target demersal fish to evaluate the capabilities of the acoustic camera. This species was identified by combining morphological and behavioral characteristics (1) the shape of the acoustic signal, (2) the size of the signal, (3) swimming behavior and (4) depth of occurrence. Such criteria were supported by the comparisons between the acoustic signal and visual identification of 7 captured individuals when both methodologies (fishing and acoustic camera) were used on the same individuals at the same time. Acoustic shadow and swimming behavior were considered major criteria for identifying species because cubera snapper (Lutjanus cyanopterus), morphologically similar to goliath groupers and occupying the same habitat [50], would have been difficult to distinguish with the P900-130 BlueView camera. However, L. cyanopterus is behaviorally more active and swims faster than goliath groupers. Thus, it is considered unlikely that this species would bias data on goliath groupers. In all cases, acoustic imagery was analyzed by a specialist of marine species of French Guiana in order to minimize identification errors.

Identification errors were also minimized by removing individuals $<40 \mathrm{~cm}$. Since the goliath grouper population around rocky sites was described as composed of few individuals $<60 \mathrm{~cm}$, the abundance estimated with the acoustic camera should not be biased significantly [51]. Indeed, juveniles of goliath groupers $(<120 \mathrm{~cm})$ occupy another habitat (mangroves) during their first years of life [32,52].

\subsection{Accuracy of Measurement with an Acoustic Camera}

Mean sizes of individuals detected with the acoustic camera were smaller than those of individuals caught during the scientific fishing survey. Such a difference where estimated sizes with the acoustic camera were slightly lower than sizes of captured fish was observed previously $[18,53,54]$. Three reasons could explain this difference: (1) measurements with an acoustic camera depend on the angle of the fish in the acoustic beam (Figure 3) and the degree of reflectiveness of fishtails; (2) Measurement errors could also be due to the active behavior of the fish that does not allow a suitable image to measure [18], and (3) measurement of the fish on deck may be biased upward because some may measure by following the contour of the fish rather than measuring the straight line distance. Such an error could increase the size of the fish by approximately $5 \%$, whereas measurements of acoustic images are always a straight line.

Nevertheless, regardless of the method of measurement (direct measurement on deck or measurement via acoustic camera), patterns of size distribution were similar: small individuals around Rémire islands and larger ones around the Grand Connétable Island MPA. Even if sizes were underestimated with the acoustic camera, this method still allows scientific studies on temporal and spatial patterns of fish size, giving a measure of relative size rather than absolute size (the same protocol must be used) and has the advantage of being more efficient than fishing surveys. In addition, with large fish like goliath groupers, acoustic size estimates provide confidence in identification, which minimizes counting error.

\subsection{Stock Assessment with an Acoustic Camera}

Besides identification and measurement errors, an acoustic camera could have other limitations resulting in an under or overestimation of fish abundance. Immobile individuals on the bottom are not counted because they can be confused with rocks. Such an error would cause underestimation of actual abundance. This bias could be minimized by 
combining stationary and mobile surveys because stationary surveys allow time to observe fish movement. However, stationary surveys produce another bias because fish can leave the acoustic camera field-of-view then return to the field, leading to multiple counts on the same individual and resulting in an overestimation of abundance. Over-counting was minimized by measuring individuals, but errors could result from counting fish of the same size.

Quantification of counting bias was not possible during the present study because visual counting was not possible in French Guiana relative to studies in other areas [12,14]. However, the repeatability of the method showed that the results are reliable, and its reproducibility could be used to study inter or intra annual variation of the total abundance of a demersal species with a P900-130 BlueView acoustic camera.

Even if goliath groupers show strong home-site fidelity, remaining on the same site year-round, it would not have been possible to estimate the number of individuals using mark/recapture data because study sites were fished, and many fishers did not participate in this study. The acoustic camera, even with its limitations, is a powerful tool to quantify the abundance of marine species [48]. In this study, it was clear that the efficiency of the acoustic camera was much greater than that of fishing.

By combining mobile and stationary surveys, it was possible to improve the detection of individuals (16\% more individuals) and, therefore to minimize the counting bias on immobile individuals [29].

Abundance estimated with the acoustic camera followed the same trend as counting derived from fishing (higher abundance in the Grand Connétable MPA than Rémire islands; higher abundance in 2011 than in 2012). Since there was no other possible methodology to study abundance in turbid and shallow waters and that estimation via fishing method "failed", acoustic cameras appeared as the most appropriate tool to perform spatial and temporal surveys of demersal fish populations in the turbid environment of French Guiana. Abundances found for goliath groupers in September, between 163 and 217 individuals around rocky areas in front of Cayenne, need to be confirmed at different times of the year. Multiple seasonal surveys with the acoustic camera would accurately estimate intra-annual variation of abundance around the islands. Therefore, seasonal acoustic surveys would improve data for stock assessments. Such an approach may also provide information on the most efficient time (most representative of the standing population) to take the survey if deployment of the acoustic camera is limited.

\subsection{Spatial Distribution}

Goliath grouper were mostly caught at the east and southeast part of islands where the prevailing current was greatest. None were caught away from the current even though fishing was attempted in these areas. Prevailing currents are oriented north-northwest because of Guianas current [55-57]. Thus, the east coasts of the islands are exposed to the wave action, whereas the west coasts are protected, with far less wave action. On the windward side of the islands, baits went close to rocky habitats, but on the calm shore, they moved away to muddy areas. Since goliath groupers are restricted to rocky habitats, this bias could explain the restricted spatial habitat found with the fishing survey. Moreover, fishing is always biased by the feeding behavior and the previous dietary intake. A way to avoid these limitations would be to change the fishing method (fishing nets instead of fishing rods), but it would be destructive for fish populations and is not always possible, especially in rocky habitats.

Acoustic cameras overcame the fishing sampling limitations (current constraints, dietary intake and behavior) and enabled the exploration of an area wider than that fished and also to locate additional habitats used by the species. On offshore sites (Grand Connétable Island MPA), the presence of goliath groupers was confirmed all around the island, exposed or protected sides. On inshore sites (Rémire islands), individuals were detected all around islands, with the exception of the southwest side. 
Briefly, after 68 fishing trips in two years, the spatial distribution of targeted species was less representative than a half-day working around an island with an acoustic camera. Analyzing the acoustic camera data is time-consuming, and the method has its own limitations; however, it is clearly more appropriate than fishing to determine the spatial distribution of large demersal fish species in the extremely turbid waters of French Guiana.

\subsection{Using an Acoustic Camera in Extremely Turbid Environment}

The first use of an acoustic camera for the purposes of assessing the abundance and diversity of marine organisms in the extremely turbid waters of French Guiana was described. All rocky areas between Cayenne and the Approuague River Estuary, representing $12 \mathrm{~km}$ of coastline, were surveyed and recorded with the P900-130 BlueView acoustic camera. The camera allowed overcoming limitations imposed by extreme turbidity [6]. Marine species with a characteristic shape (ray, turtles, and sharks) were easily identified, even at a species level, based on their silhouette (for example, manta ray and long nose ray). However, these criteria were not adequate for species with similar morphology, such as most fish, for which other criteria, such as the swimming behavior, were needed. Fish swimming behavior was previously used as an additional character in acoustic-mediated identification [49]. However, it was not possible to identify all fish species with a P900-130 BlueView, in particular, species smaller than $40 \mathrm{~cm}$.

Acoustic cameras are useful in some situations, but usefulness depends on the scientific question. The goal of many studies using acoustic cameras has been to study the total abundance of fish in habitats of limited visibility $[8,14,15,19]$, or to focus on one species that was morphologically different from all other species $[17,26]$. Most studies attempting identification to a species level were carried out with a DIDSON camera at a high frequency $(1.8 \mathrm{MHz})[3,9]$, which is twice the frequency of the P900-130 BlueView. Higher frequencies typically produce clearer images; thus, it would be interesting to compare both types of acoustic cameras in French Guiana.

Nevertheless, the use of the ProViewer provides sufficient resolution of certain marine animals, those with distinct morphology and/or behaviors, for identification and measurement and is therefore useful for assessment of stock status for those species. In addition, for some species, juveniles can be distinguished from adults (e.g., marine turtles, sharks and goliath groupers) because maturity is a function of size. In French Guiana, such information could be used to develop an effective program for marine ecosystem management.

\section{Conclusions}

Acoustic camera surveys were demonstrated to be an effective method to assess stocks of large fish species. The P900-130 BlueView model allows the identification of demersal fish like goliath groupers while swimming. For smaller mobile species, it would be necessary to increase the video resolution with a more powerful model with higher frequencies. Using methods described in this study, it is possible, with the appropriate species, to evaluate spatial distribution, assess the total abundance and describe the total length; no other method has these capabilities in extremely turbid waters. This approach should be extended to other demersal or large pelagic species in the French Guiana region to fill the current lack of knowledge in marine species ecology.

Author Contributions: Conceptualization, C.A., S.M. and L.L.; methodology, C.A., S.M., E.B., C.V. and C.N.; software, C.A. and S.M.; validation, C.A. and L.L.; formal analysis, C.A.; investigation, C.A.; resources, S.M., E.B., C.V. and C.N.; data curation, C.A.; writing-original draft preparation, C.A.; writing-review and editing, R.B., L.L., C.C.K. and C.N.; visualization, C.A.; supervision, L.L. and C.C.K.; project administration, R.B.; funding acquisition, C.A. All authors have read and agreed to the published version of the manuscript.

Funding: This research was funded by Direction De L'environnement, De L'aménagement et du Logement (DEAL) and Agence Des Aires Marines Protégées (AMP). 
Institutional Review Board Statement: Not applicable.

Informed Consent Statement: Not applicable.

Data Availability Statement: The data presented in this study are available on request from the corresponding author. The data are not publicly available due to a data moratorium.

Acknowledgments: This study was done in partial fulfillment of the degree of doctor of marine biology at the University of French West Indies and French Guiana (CA). We thank the Grand Connétable reserve agents, A. Alcide and A. Hauselmann, for providing access to the field and the MPA in their research vessel and the Association des plaisanciers et pêcheurs de Guyane (APPG), especially E. Ribas for his involvement and support in the grouper project. We thank L. Scott for proofreading the manuscript and improving the English language. We also thank the Office National de la Chasse et de la Faune Sauvage (ONCFS), today called Office Français de la Biodiversité, for the administrative and financial management of the grouper project.

Conflicts of Interest: The authors declare no conflict of interest. The funders had no role in the design of the study, in the collection, analyses, or interpretation of data, in the writing of the manuscript, or in the decision to publish the results.

\section{References}

1. Baumgartner, L.J.; Reynoldson, N.; Cameron, L.; Stanger, J. Assessment of a Dual-frequency Identification Sonar (DIDSON) for application in fish migration studies. ICES Doc. 2006, 84, 1-33.

2. Belcher, E.O.; Matsuyama, B.; Trimble, G. Object Identification with acoustic lenses. In Proceedings of the MTS/IEEE Oceans 2001, An Ocean Odyssey, Conference Proceedings (IEEE Cat. No.01CH37295), Honolulu, HI, USA, 5-8 November 2001; pp. 6-11.

3. Langkau, M.C.; Balk, H.; Schmidt, M.B.; Borcherding, J. Can acoustic shadows identify fish species? A novel application of imaging sonar data. Fish. Manag. Ecol. 2012, 19, 313-322. [CrossRef]

4. Tiffan, K.F.; Rondorf, D.W.; Skalicky, J.J. Imaging Fall Chinook Salmon Redds in the Columbia River with a Dual-Frequency Identification Sonar. N. Am. J. Fish. Manag. 2004, 24, 1421-1426. [CrossRef]

5. Hubert, W.A.; Pope, K.L.; Dettmers, J.M. Passive capture techniques. In Fisheries Techniques, 3rd ed.; Zale, A.V., Parrish, D.L., Sutton, T.M., Eds.; American Fisheries Society: Bethesda, MD, USA, 2012; pp. 223-265. ISBN 1-888569-00-X.

6. Belcher, E.O.; Lynn, D.C. Acoustic near-video quality images for work in turbid water. In Proceedings of the Underwater Intervention, Houston, TX, USA, 24-26 January 2000.

7. Kim, K.; Neretti, N.; Intrator, N. Mosaicing of acoustic camera images. IEE Proc. Radar. Sonar Navig. 2005, 152, 263-270. [CrossRef]

8. Kang, M.-H. Semiautomated analysis of data from an imaging sonar for fish counting, sizing, and tracking in a post-processing application. Fish. Aquat. Sci. 2011, 14, 218-225. [CrossRef]

9. Moursund, R.A.; Carlson, T.J.; Peters, R.D. A fisheries application of a dual-frequency identification sonar acoustic camera. ICES J. Mar. Sci. J. Cons. 2003, 60, 678-683. [CrossRef]

10. Graham, N.; Jones, E.G.; Reid, D.G. Review of technological advances for the study of fish behaviour in relation to demersal fishing trawls. ICES J. Mar. Sci. J. Cons. 2004, 61, 1036-1043. [CrossRef]

11. Martignac, F.; Daroux, A.; Bagliniere, J.L.; Ombredane, D.; Guillard, J. The use of acoustic cameras in shallow waters: New hydroacoustic tools for monitoring migratory fish population. A review of DIDSON technology. Fish. Fish. 2015, 16, 486-510. [CrossRef]

12. Holmes, J.A.; Cronkite, G.M.W.; Enzenhofer, H.J.; Mulligan, T.J. Accuracy and precision of fish-count data from a "dual-frequency identification sonar" (DIDSON) imaging system. ICES J. Mar. Sci. J. Cons. 2006, 63, 543-555. [CrossRef]

13. Burwen, D.L.; Fleischman, S.J.; Miller, J.D. Evaluation of a Dual-Frequency Imaging Sonar for Detecting and Estimating Fish Size in the Kenai River; Fisheries Data Series No 07-44; Alaska Department of Fish and Game: Anchorage, AK, USA, 2007 ; ISBN 1800478364.

14. Maxwell, S.L.; Gove, N.E. Assessing a dual-frequency identification sonars' fish-counting accuracy, precision, and turbid river range capability. J. Acoust. Soc. Am. 2007, 122, 3364-3377. [CrossRef]

15. Boswell, K.M.; Wilson, M.P.; Cowan, J.H. A Semiautomated Approach to Estimating Fish Size, Abundance, and Behavior from Dual-Frequency Identification Sonar (DIDSON) Data. N. Am. J. Fish. Manag. 2008, 28, 799-807. [CrossRef]

16. Han, J.; Honda, N.; Asada, A.; Shibata, K. Automated acoustic method for counting and sizing farmed fish during transfer using DIDSON. Fish. Sci. 2009, 75, 1359. [CrossRef]

17. Pavlov, D.S.; Borisenko, E.S.; Pashin, V.M. Investigations of spawning migration and assessment of abundance of the Kamchatka steelhead (Parasalmo mykiss) from the Utkholok River by means of Didson dual-frequency identification sonar. J. Ichthyol. 2009, 49, 1042. [CrossRef]

18. Burwen, D.L.; Fleischman, S.J.; Miller, J.D. Accuracy and Precision of Salmon Length Estimates Taken from DIDSON Sonar Images. Trans. Am. Fish. Soc. 2010, 139, 1306-1314. [CrossRef]

19. Becker, A.; Whitfield, A.K.; Cowley, P.D.; Järnegren, J.; Næsje, T.F. An assessment of the size structure, distribution and behaviour of fish populations within a temporarily closed estuary using dual frequency identification sonar (DIDSON). J. Fish. Biol. 2011, 79, 761-775. [CrossRef] 
20. Pham, A.H.; Lundgren, B.; Stage, B.; Jensen, J.A. Ultrasound backscatter from free-swimming fish at $1 \mathrm{MHz}$ for fish identification. IEEE Int. Ultrason. Symp. IUS 2012, 1477-1480. [CrossRef]

21. Khan, F.; Royer, G.E.; Johnson, G.E.; Phillips, N.R.; Ham, K.D.; Hughes, J.S.; Fischer, E.S.; Ploskey, G.R. Acoustic Imaging Evaluation of Juvenile Salmonid Behavior in the Immediate Forebay of the Water Temperature Control. Tower at Cougar Dam 2010; Pacific Northwest National Lab. (PNNL): Washington, DC, USA, 2012.

22. Baumgartner, L.; Bettanin, M.; McPherson, J.; Jones, M.; Zampatti, B.; Beyer, K. Assessment of an infrared fish counter (Vaki Riverwatcher) to quantify fish migrations in the Murray-Darling Basin. Aust. J. Zool. 2010, 58, 154-164. [CrossRef]

23. Gledhill, C.T.; Lyczkowski-Shultz, J.; Rademacher, K.; Kargard, E.; Crist, G.; Grace, M.A. Evaluation of video and acoustic index methods for assessing reef-fish populations. ICES J. Mar. Sci. 1996, 53, 483-485. [CrossRef]

24. Koslow, J.A.; Kloser, R.; Stanley, C.A. Avoidance of a camera system by a deepwater fish, the orange roughy (Hoplostethus atlanticus). Deep. Res. Part. I Oceanogr. Res. Pap. 1995, 42, 233-244. [CrossRef]

25. Rose, C.S.; Stoner, A.W.; Matteson, K. Use of high-frequency imaging sonar to observe fish behaviour near baited fishing gears. Fish. Res. 2005, 76, 291-304. [CrossRef]

26. Pipal, K.; Jessop, M.; Boughton, D.; Adams, P. Using dual-frequency identification sonar (DIDSON) to estimate adult steelhead escapement in the San Lorenzo river, California. Calif. Fish. Game 2010, 96, 90-95.

27. McCauley, D.J.; DeSalles, P.A.; Young, H.S.; Gardner, J.P.; Micheli, F. Use of high-resolution acoustic cameras to study reef shark behavioral ecology. J. Exp. Mar. Bio. Ecol. 2016, 482, 128-133. [CrossRef]

28. Shen, W.; Yang, L.; Zhang, J.; Peng, G. The Survey of Fishery Resources and Spatial Distribution Using DIDSON Imaging Sonar Data. In Computer and Computing Technologies in Agriculture VI: 6th IFIP WG 5.14 International Conference, CCTA 2012, Zhangjiajie, China, 19-21 October 2012, Revised Selected Papers, Part I; Li, D., Chen, Y., Eds.; Springer: Berlin/Heidelberg, Germany, 2013; pp. 366-375. ISBN 978-3-642-36124-1.

29. Frias-Torres, S.; Luo, J. Using dual-frequency sonar to detect juvenile goliath grouper Epinephelus itajara in mangrove habitat. Endanger. Species Res. 2009, 7, 237-242. [CrossRef]

30. Sadovy, Y.; Eklund, A.M. Synopsis of biological data on the Nassau grouper, Epinephelus striatus (Bloch, 1792), and the jewfish, E. itajara (Lichenstein, 1822). In Fao Fish. Synop. 157; NOAA Tech. Rep. NMFS 146; NOAA/National Marine Fisheries Service: Seattle, WA, USA, 1999; 65p.

31. Gerhardinger, L.C.; Bertoncini, A.A.; Hostim-silva, M. Local ecological knowledge and Goliath grouper spawning aggregations in the South Atlantic Ocean: Goliath grouper spawning aggregations in Brazil. SPC Tradit. Mar. Resour. Manag. Knowl. Inf. Bull. 2006, 20, 33-34.

32. Koenig, C.C.; Coleman, F.C.; Eklund, A.M.; Schull, J.; Ueland, J. Mangroves as essential nursery habitat for goliath grouper (Epinephelus itajara). Bull. Mar. Sci. 2007, 80, 567-586.

33. Gerhardinger, L.C.; Hostim-Silva, M.; Medeiros, R.P.; Matarezi, J.; Bertoncini, Á.A.; Freitas, M.O.; Ferreira, B.P. Fishers' resource mapping and goliath grouper Epinephelus itajara (Serranidae) conservation in Brazil. Neotrop. Ichthyol. 2009, 7, 93-102. [CrossRef]

34. Craig, M.T. Epinephelus Itajara. Available online: www.iucnredlist.org (accessed on 13 October 2014).

35. Orseau, S.; Lesourd, S.; Huybrechts, N.; Gardel, A. Hydro-sedimentary processes of a shallow tropical estuary under Amazon influence. The Mahury Estuary, French Guiana. Estuar. Coast. Shelf Sci. 2017, 189, 252-266. [CrossRef]

36. Pujos, M.; Froidefond, J.M. Water masses and suspended matter circulation on the French Guiana continental shelf. Cont. Shelf Res. 1995, 15, 1157-1171. [CrossRef]

37. Abascal-Zorrilla, N.; Vantrepotte, V.; Huybrechts, N.; Ngoc, D.D.; Anthony, E.J.; Gardel, A. Dynamics of the estuarine turbidity maximum zone from landsat-8 data: The case of the maroni river Estuary, French Guiana. Remote Sens. 2020, 12, 2173. [CrossRef]

38. Froidefond, J.M.; Lahet, F.; Hu, C.; Doxaran, D.; Guiral, D.; Prost, M.T.; Ternon, J.F. Mudflats and mud suspension observed from satellite data in French Guiana. Mar. Geol. 2004, 208, 153-168. [CrossRef]

39. Shi, W.; Wang, M. Characterization of global ocean turbidity from moderate resolution imaging spectroradiometer ocean color observations. J. Geophys. Res. Ocean. 2010, 115, 1-14. [CrossRef]

40. Ffield, A. North Brazil current rings viewed by TRMM Microwave Imager SST and the influence of the Amazon Plume. Deep Sea Res. Part. I Oceanogr. Res. Pap. 2005, 52, 137-160. [CrossRef]

41. Hellweger, F.L.; Gordon, A.L. Tracing Amazon River water into the Caribbean Sea. J. Mar. Res. 2002, 60, 537-549. [CrossRef]

42. Richardson, P.L.; Hufford, G.E.; Limeburner, R.; Brown, W.S. North Brazil Current retrofiection eddies Woods Hole Oceanographic Institution, Woods Hole, Massachusetts. J. Geophys. Res. 1994, 99, 5081-5093. [CrossRef]

43. Pina-Amargós, F.; González-Sansón, G. Movement patterns of goliath grouper Epinephelus itajara around southeast Cuba: Implications for conservation. Endanger. Species Res. 2009, 7, 243-247. [CrossRef]

44. Koenig, C.C.; Coleman, F.C. The Recovering Goliath Grouper Population of the Southeastern US: Non-Consumptive Investigations for Stock Assessment. National Oceanic and Atmospheric Administration MARFIN Project FINAL Report; NOAA: St Teresa, FL, USA, 2013.

45. Artero, C. Biologie et Ecologie du Mérou Géant, Epinephelus Itajara, en Guyane Française. Ph.D. Thesis, Université des Antilles et de la Guyane, Cayenne, France, 2014.

46. Graves, J.E.; Luckhurst, B.E.; Prince, E.D. An evaluation of pop-up satellite tags for estimating postrelease survival of blue marlin (Makaira nigricans) from a recreational fishery. Fish. Bull. USA 2002, 100, 134-142. 
47. Horodysky, A.Z.; Graves, J.E. Application of pop-up satellite archival tag technology to estimate postrelease survival of white marlin (Tetrapturus albidus) caught on circle and straight-shank ("J") hooks in the western North Atlantic recreational fishery. Fish. Bull. 2005, 103, 84-96.

48. Han, C.-H.; Uye, S.-I. Quantification of the abundance and distribution of the common jellyfish Aurelia aurita s.l. with a Dual-frequency IDentification SONar (DIDSON). J. Plankt. Res. 2009. [CrossRef]

49. Doehring, K.; Young, R.G.; Hay, J.; Quarterman, A.J. Suitability of Dual-frequency Identification Sonar (DIDSON) to monitor juvenile fish movement at floodgates. N. Z. J. Mar. Freshw. Res. 2011, 45, 413-422. [CrossRef]

50. Allen, G. Fao Species Catalogue Vol. 6. Snappers of the World. An annotated and illustrated catalogue of lutjanid species known to date. FAO Fish. Synop. 1985, 6, 208.

51. Artero, C.; Murie, D.J.; Koenig, C.C.; Berzins, R.; Bouchon, C.; Lampert, L. Age, growth, and mortality of the Atlantic goliath grouper Epinephelus itajara in French Guiana. Endanger. Species Res. 2015. [CrossRef]

52. Artero, C.; Koenig, C.C.; Richard, P.; Berzins, R.; Guillou, G.; Bouchon, C.; Lampert, L. Ontogenetic dietary and habitat shifts in goliath grouper Epinephelus itajara from French Guiana. Endanger. Species Res. 2015. [CrossRef]

53. Daroux, A.; Martignac, F.; Nevoux, M.; Baglinière, J.L.; Ombredane, D.; Guillard, J. Manual fish length measurement accuracy for adult river fish using an acoustic camera (DIDSON). J. Fish. Biol. 2019, 95, 480-489. [CrossRef] [PubMed]

54. Tušer, M.; Frouzová, J.; Balk, H.; Muška, M.; Mrkvička, T.; Kubečka, J. Evaluation of potential bias in observing fish with a DIDSON acoustic camera. Fish. Res. 2014, 155, 114-121. [CrossRef]

55. Johns, W.E.; Lee, T.N.; Schott, F.A.; Zantopp, R.J.; Evans, R.H. The North Brazil Current Retrofiection: Seasonal Structure and Eddy Variability. J. Geophys. Res. Ocean. 1990, 95, 22103-22120. [CrossRef]

56. Stramma, L.; Schott, F. The mean flow field of the tropical Atlantic Ocean. Deep Sea Res. Part. II Top. Stud. Oceanogr. 1999, 46, 279-303. [CrossRef]

57. Memery, L.; Arhan, M.; Alvarez-Salgado, X.A.; Messias, M.J.; Mercier, H.; Castro, C.G.; Rios, A.F. The water masses along the western boundary of the south and equatorial Atlantic. Prog. Oceanogr. 2000, 47, 69-98. [CrossRef] 